\title{
The Stava mudflow of 19 July 1985 (Northern Italy): a disaster that effective regulation might have prevented
}

\author{
F. Luino ${ }^{1}$ and J. V. De Graff ${ }^{2}$ \\ ${ }^{1}$ Consiglio Nazionale delle Ricerche, Istituto di Ricerca per la Protezione Idrogeologica (CNR-IRPI), Strada delle Cacce, 73, \\ 10135 Torino, Italy \\ ${ }^{2}$ USDA Forest Service, 1600 Tollhouse Road, CLOVIS, CA 93611, USA \\ Correspondence to: F. Luino (fabio.luino@irpi.cnr.it)
}

Received: 9 January 2012 - Revised: 27 February 2012 - Accepted: 27 February 2012 - Published: 16 April 2012

\begin{abstract}
The disaster occurring in the Eastern Italian Alps in the summer of 1985 was caused by the failure of two tailings dams located just upstream from the village of Stava in the municipality of Tesero (Trento province, Italy). The structure comprised two small storage basins for the deposition of tailings from the separation process of the Prestavel fluorite mine. On their downstream sides, the basins were contained by steep earth embankments, whereas upstream they rested directly on the natural slope. The total height from the base of the lower dam to the crest of the upper dam was over $50 \mathrm{~m}$.
\end{abstract}

On 19 July 1985, the front of the upper dam suddenly burst, triggering a vast mudflow $\left(180000 \mathrm{~m}^{3}\right)$ that flowed down-channel through Stava, a small village of 20 buildings. The mudflow rapidly traveled over $4.2 \mathrm{~km}$ along the Stava Valley and passed through Tesero, before flowing into the Avisio River. The mudflow destroyed many buildings and resulted in 268 fatalities and 20 injuries. From an analysis of the data collected and field observation, several factors may be cited as having contributed to increasing instability, as the upper dam continued to be raised until the disastrous collapse of 19 July. Foremost among these factors is the mistaken assumption that the tailings deposited in the impoundments would consolidate fairly quickly. Indeed, no monitoring system was ever installed to verify the assumed consolidation. Other operational shortcomings and construction errors were contributing factors. Regulations requiring construction standards, operational monitoring, and independent periodic inspection could have prevented this disaster. Comprehensive legislation is required to effectively limit the adverse consequences of tailings dam failures by providing a regulatory environment where the safety and welfare of the local area can be balanced with the economic benefits of mining operations.

\section{Introduction}

Building codes and construction standards ensure the safety and function of the environment in which we live and work. While these codes and standards are typically adopted at a national level, their application and enforcement is commonly the responsibility of counties, municipalities, and towns. This local application and enforcement is crucial to transforming the intent, represented by the codes and standards, into the reality of safe, functional structures and facilities we depend on every day. Certain specialized structures and facilities may have national standards, which are applied through specialized national or regional government agencies. This is often the case for large dams used for hydroelectric generation, water resources, and flood control. However, it is not uncommon for local government to be responsible for the application and enforcement of standards for smaller dams. Dams needed to impound tailings from mine operations would be included among the small dams where local governments would exert this authority.

Tailing impoundment dams represent a specialized class of this type of structure. Large dams are commonly designed with the expectation that the structure will exist for a long time. The design life for major structures is usually between 50 and 100 years. This design life can be extended by careful maintenance of a well-placed and well-designed large dam. 


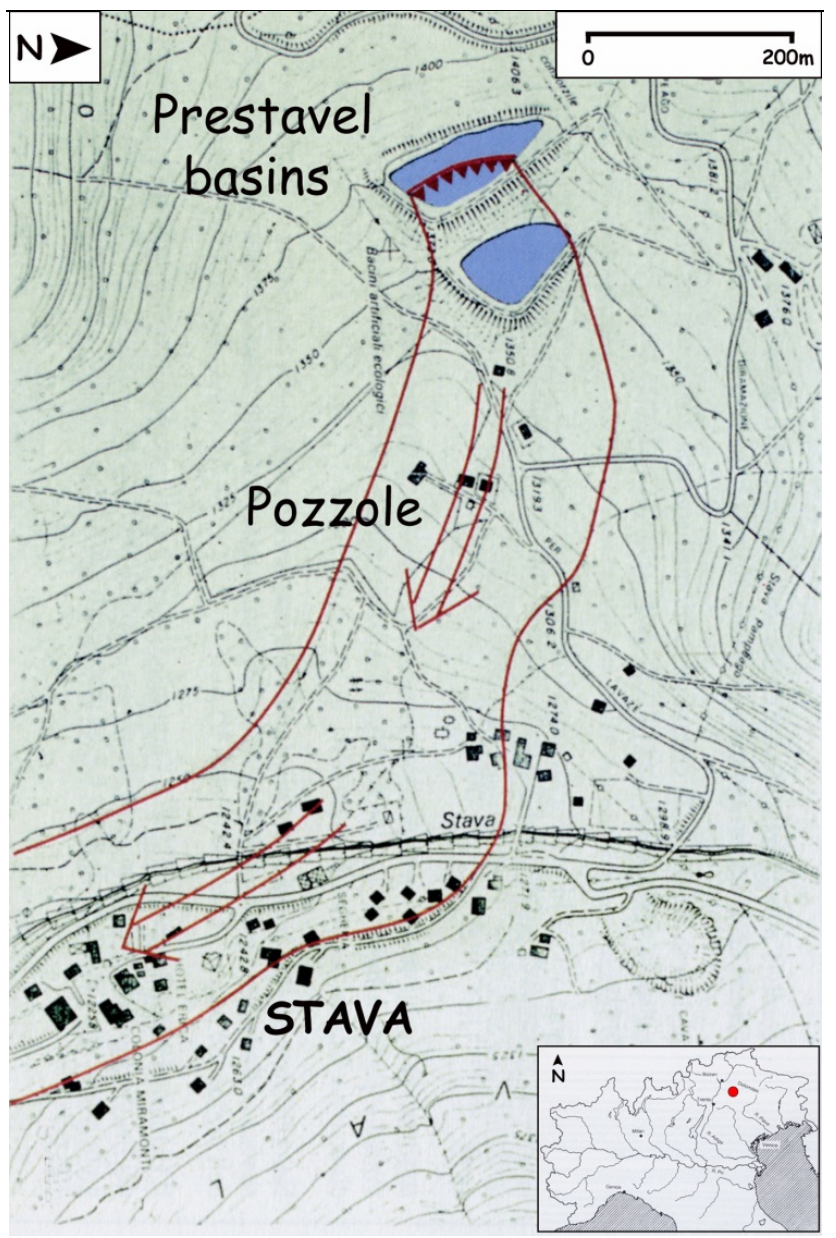

Fig. 1. Stava village and the Prestavel basins in the official map before the collapse. Red lines show failure and the path of the mudflow (courtesy of Fondazione Stava, 1985).

Most people expect a large dam will continue to be in service beyond their lifetime. In contrast, the design life of tailing dams is determined by the operational life of the mine, the period that processing will generate tailings for disposal, or the physical site conditions that may limit future expansion. Once the need for a particular tailings dam ceases, it is expected that reclamation of the dam and tailings will result in their becoming a stable feature within the local landscape.

Failures of tailings dams have caused injuries and fatalities, damaged and destroyed property, and inflicted environmental damage worldwide (Rico et al., 2008; WUP, 2011). As recently as the period from July 2009 to July 2011, major failures are known to have taken place in China, Hungary, Russia, and Peru (WUP, 2011). It is unlikely that these are the only occurrences during this period. The 2010 release of $700000 \mathrm{~m}^{3}$ of caustic, bright red slurry in Kolontár, Hungary from the tailings dam failure at the MAL Magyar Aluminum plant was a graphic recent event seen by television news viewers around the globe. Rico et al. (2008) reviewed available databases for reported tailings dam failures worldwide through 2007. Their analysis found that over $85 \%$ of the incidents involved tailings dams associated with active operations. Also, they identified five characteristics that result in tailings dams being more prone to failure than other comparable dam types (Rico et al., 2008): (1) embankments formed by locally collected fills (soil, coarse waste, slurry from mining operations and tailings); (2) dams subsequently raised as solid material coupled with a severe increase in effluent (plus runoff precipitation); (3) lack of regulations on specific design criteria; (4) lack of dam stability requirements regarding continuous monitoring and control during emplacement, construction and operation; (5) high cost of maintenance work for tailings dams after closure of mining activities. This paper will look at a well-documented example of a tailings dam failure, the 1985 Stava, Italy event. This case study will illustrate how this disaster was more a result of improper application of technical knowledge than the lack of that knowledge. It will also demonstrate that continued adverse impacts on local populations has more to do with the absence of a legislative framework for regulating these facilities than a lack of understanding of basic factors leading to catastrophic failure.

\section{The event}

At twenty-three minutes after noon on 19 July 1985, the upper dam of two silting basins used for the disposal and cleansing of fluorite mine tailings collapsed. The resulting rift allowed water and sediment to pour into the lower impoundment, which also collapsed. This mixture of water, sediment and debris became a mudflow that spanned about $250 \mathrm{~m}$ upstream from Stava (municipality of Tesero, Val di Fiemme, province of Trento). As the mudflow passed through Stava, it razed all 20 buildings before continuing along the Stava Valley before passing through Tesero and flowing into the Avisio River. This catastrophic mudflow rapidly traveled $4.2 \mathrm{~km}$ along the Stava valley. In addition to buildings destroyed along its track, 268 lives were lost, 100 people were injured and only 8 victims rescued alive (Lucchi, 2002). The disaster caused damage valued at about 133 million euros (Lucchi, 2011).

\section{Characteristics of the Prestavel mine tailings impoundments}

Information on the Prestavel basins was taken from documents describing the technical characteristics of the tailings impoundments (C.T.A., 1986). Just prior to the disaster, the disposal facility comprised two impoundments containing the wet, fine-grained particles(referred to as silt) from the cleansing of waste materials extracted from the Prestavel mine (Fig. 1). The impoundments were arranged in step form so that the upper basin decanted into the lower one. 


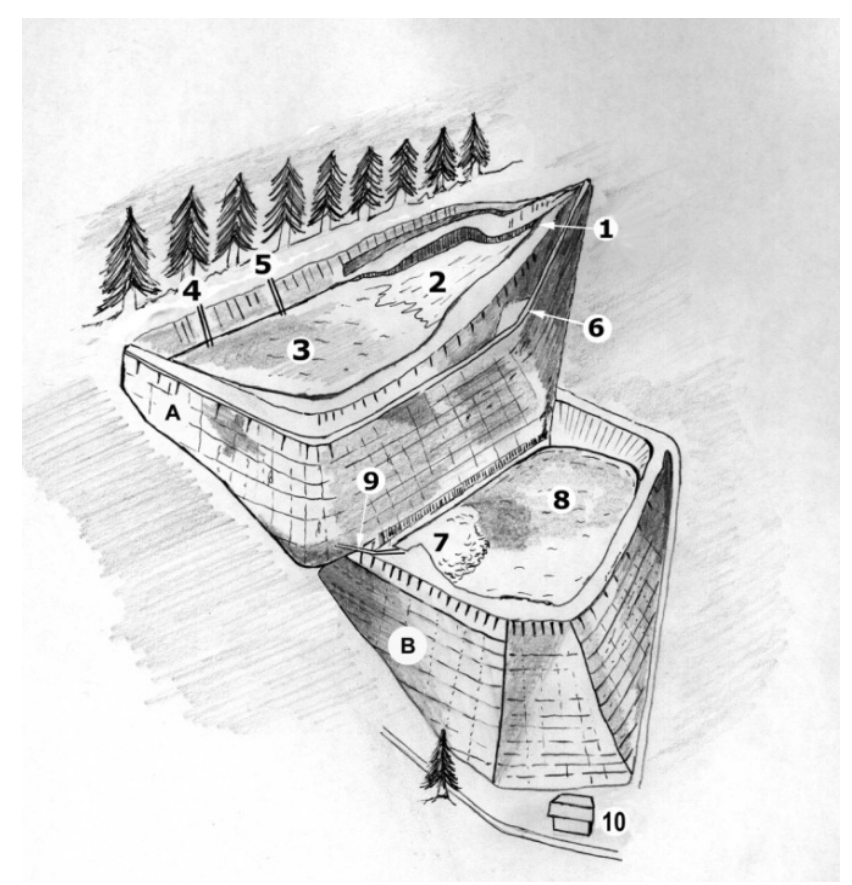

Fig. 2. Graphical representation of the Prestavel basins: (A) upper basin; (B) lower basin; (1) cyclone, (2) sandy deposit, (3) silty deposit, (4) drainage service, (5) emergency drainage,(6) service road, (7) sand cone, (8) silty deposit, (9) drainage from the upper basin, (10) caretaker's house.

Both basins had earth dams facing the valley and the mountain slopes. Laterally, the upper basin dam abutted against a densely forested slope. Its front embankment rested partly on the silt of the lower basin; this configuration reduced the surface area of the dam face (Fig. 2). Structurally, the dams were composed principally of medium-fine sand and thin or fairly uniform layers of saturated clayey silt.

The elevation of the lower impoundment was $1350.80 \mathrm{~m}$, or a maximum dam height over ground level of about 22$23 \mathrm{~m}$. At the time of the disaster, the maximum elevation of the dam crest was $1378.83 \mathrm{~m}$, or a maximum dam height of about $28 \mathrm{~m}$. Viewed as a single section, with one dam face directly above the other, the structure was presented as a loose earth embankment over $50 \mathrm{~m}$ high (Fig. 3).

After the creation of the upper impoundment, the surface area of the lower impoundment was about $6500 \mathrm{~m}^{2}$ and its storage capacity about $100000 \mathrm{~m}^{3}$. The upper impoundment, located immediately behind and upstream from the lower one, had a surface area of about $9800 \mathrm{~m}^{2}$ and a storage capacity of about $150000 \mathrm{~m}^{3}$.

Analyses revealed that the geotechnical characteristics of the materials (Chandler and Tosatti, 1995) taken from the impoundment dams were remarkably homogeneous: the range of the shear strength angle was between $33^{\circ}$ and $37^{\circ}$; the cohesion was zero (the Atterberg limits were either not determinable or gave consistency indices (CI) between -0.4

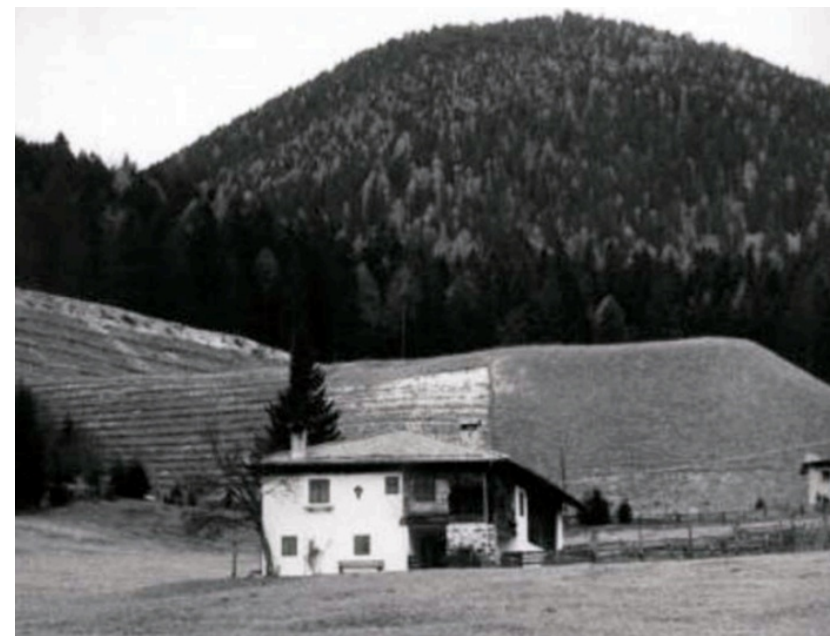

Fig. 3. 1981-1982: bottom view of the two basins almost completely replanted. It is possible to notice the progressive levels of growth achieved by hydrocyclone and the caretaker's house in the foreground (courtesy of Fondazione Stava, 1985).

and 0); only one sample from all those known taken had a CI of 0.2 ; the permeability coefficients $(k)$ at the site and in the laboratory varied between $10^{-3}$ and $10^{-6} \mathrm{~cm} \mathrm{~s}^{-1}$ depending on the type of material, moisture, and density.

Because the sands came from the grinding and cleansing of materials extracted from the mine, they were more coarse and well-classified (uniformity coefficient between 2 and 4 ); because of their grain size and permeability coefficient $(k=$ $10^{-3}-10^{-4} \mathrm{~cm} \mathrm{~s}^{-1}$ ), they were considered suitable for dam construction.

The investigations also showed that while the lower dam rested on natural ground, the upper basin rested on natural ground only along its sides, whereas its front embankment, judging from a reconstruction of the dam geometries prior to collapse, rested, in part, on the sediments of the lower impoundment. The fine sands constituting the dams and nearly the entire silt in the basins, to a depth of 7-8 $\mathrm{m}$, had a moisture rate of about $20-35 \%$.

Two systems of tailings slurry disposal were employed: on-dam cycloning and central cycloning (USEPA, 1994). In on-dam cycloning, as shown in Fig. 4, the slurry is cycloned from the tailings materials using hydrocyclones moving on rails, which separate the larger tailings sand sized particles from the finer silt. The coarse materials deposit to form the dam crest, while the finer tailings are routed to the interior of the impoundment, where they deposit according to particle size, and form a sloping tailings beach surface along the interior perimeter of the dam. Central, or stationary, cycloning usually places a single cyclone over an abutment of the dam. A pool of clarified water accumulates upstream from the tailings sand beach. The dam crest is formed by cyclone sands mechanically moved from the cyclone location to the dam crest using a dragline or bulldozer. 


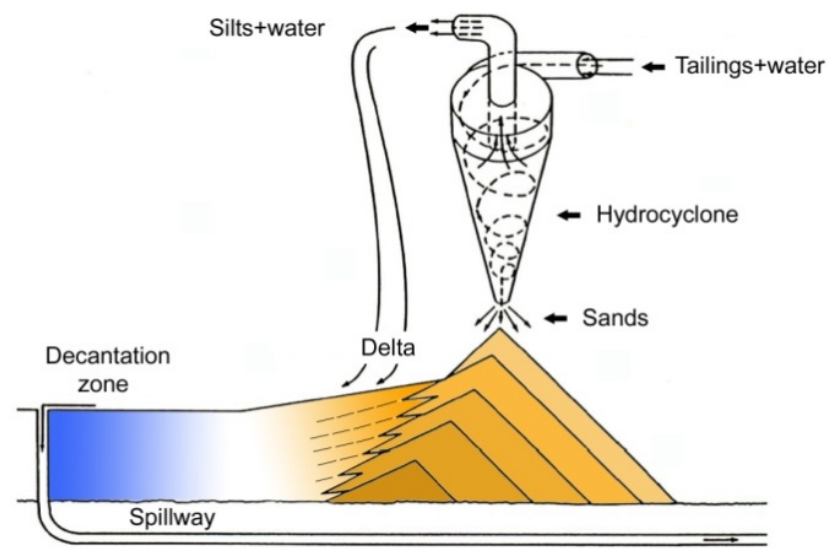

Fig. 4. The embankments of the landfill minings are made through a process of centrifugation in a hydrocyclone in which are channeled the mud; sand is separated and used to realize the embankment, while the finer fraction, constituted by silty mud to settle, is discharged into the reservoir through a pipe (from Watermeyer and Williamson, 1979, modified).

From findings in the area, photographs of the impoundments before the disaster and other sources, it appears certain that, at least within the upper basin, a fixed cyclone at the northern edge of the upper impoundment was used during the last three years of operation. After densification, the hydrocycloned sands went into the construction of the dam raise near the cyclone, whereas the remaining part of the dam was constructed by mechanically transporting the sand from the point of deposit.

Developing a tailings sand beach along the entire internal perimeter of a dam is generally given great importance insofar as natural compaction of the deposit will ensure impermeability of the interior wall of the dam, thus, preventing filtration. In this way, risk of piping and siphoning would be prevented as would the creation of pressure heads that could destabilize the work. With this method, the downstream foot of the upper dam came to rest on the sediments of the lower impoundment. The upper dam was raised using the upstream method construction, which relied chiefly on the support of the silt deposits in the lower impoundment for subsequent raising. These deposits were, in general, diffusely composed of thin, poorly densified layers, which differed from layer to layer, with some being composed of "loose" saturated sediments and others partially cohesive. In total, about $400000 \mathrm{~m}^{3}$ of deposited material were impounded. Among all factors listed for dam failure, without doubt, the mistaken assumption that the tailings deposited in the impoundments would consolidate fairly quickly appears surely to be the main reason for the collapse.

\section{Uncontrolled development of the Prestavel mine tail- ings dams}

The first written document on the Mount Prestavel mining dates back to 1528 . While the early mining exploited argentiferous galena, fluorite became the focus of mining beginning in 1934 through to the time of the disaster. It was not this change in the ore being exploited in the Prestavel mine that led to the 1985 disaster. Rather, it was the decision to change processing methods for refining the extracted fluorite. In 1961, the operating company decided to use a flotation system in order to produce fluorite at the $97-98 \%$ purity required for the chemical industry. Until then, a gravimetric system that did not require water-produced fluorite at a purity of $75-85 \%$ was suitable for the steel industry. The flotation plant would require plenty of water and, nearby, an area suitable for decanting and landfilling the wet sludge leftover from the process. The plant was established on the mountainside, at an altitude of $1420 \mathrm{~m}$, together with an aqueduct, a cable car to transport the extracted material from the mine and a chair lift for transporting workers. The required decanting and landfilling of the process waste would utilize tailings basins formed using the waste material to construct the retaining dams. Initial processing at the plant was more than $150 \mathrm{t}$ per day with the potential for $200 \mathrm{t}$ per day.

Data on the natural conditions of the area prior to construction of the impoundment dams were gleaned from historical records to reconstruct an accurate account of the various phases of development of the two basins up to their final geometrical configuration. The analysis was based on the following documents: (a) geological, mining and technical bibliography, (b) thematic maps (IGM topography and Autonomous Province of Trento, geology and morphology), and (c) aerial photographs taken at different times.

The Prestavel mine had been in operation since the 16th century (Perna, 1964). It was initially developed for the extraction of small deposits of argentiferous galena. In 1934 mining at Prestavel was redirected to the extraction of fluorite. The processing needs of the extracted fluorite provided the impetus for construction of the tailings basins from 1961 to the time of their failure on 19 July 1985 (Table 1).

In 1961 the concessionary company built a new plant (Ministero dell'Industria Commercio Artigianato, 19351980) for separating ore from waste to process fluorine to "acid grade" (97\% CaF) for use in the chemical industry. This resulted in two significant changes in the operations at the Prestavel Mine. First, the average maximum production of mine-run material increased from the earlier rate of $30 \mathrm{tday}^{-1}$ to $200 \mathrm{tday}^{-1}$ (Morra and Vighi, 1964). Second, the processing of the extracted fluorite by washing and sorting was replaced by a floatation treatment system. Both the volume of tailings material produced and the greater amount of water involved required disposal in a tailings basin system. The first basin was constructed (i.e. the lower impoundment described in the previous section) for the disposal and 
Table 1. History of the Prestavel mining management.

\begin{tabular}{|c|c|c|c|}
\hline Time & Mine operator or concession holder & Mining operations & Tailings basins \\
\hline 1700s-1934 & $\begin{array}{l}\text { Prestavel Mine started. Various entities } \\
\text { owned or operated it }\end{array}$ & $\begin{array}{l}\text { Intermittent operations to extract small } \\
\text { deposits of argentiferous galena }\end{array}$ & \\
\hline 1934-1944 & $\begin{array}{l}\text { Società Atesina per l'Esplorazione } \\
\text { Mineraria granted } \\
6 \text { March } 1935\end{array}$ & Begins mining fluorite seams & \\
\hline 1944 & \multirow{2}{*}{ Montecatini Company } & $\begin{array}{l}\text { The maximum production rate of } \\
\text { mine-run material is } 30 \mathrm{tday}^{-1} \text { on av- } \\
\text { erage sold as flux to steel industry }\end{array}$ & \\
\hline 1961 & & $\begin{array}{l}\text { New plant installed to process fluo- } \\
\text { rine to "acid grade" ( } 97 \% \mathrm{CaF}) \text { by } \\
\text { floatation for use in the chemical indus- } \\
\text { try; mine-run material increased up to } \\
200 \text { t day }^{-1}\end{array}$ & $\begin{array}{l}\text { First tailings basin } \\
\text { (lower) constructed; } \\
\text { begins being used in } \\
1962\end{array}$ \\
\hline 1967 & $\begin{array}{l}\text { Montedison company (Montecatini } \\
\text { Edison) is granted concession on } \\
5 \text { May } 1967 \text {. }\end{array}$ & $\begin{array}{l}\text { Mining activity declines due to seams } \\
\text { playing out; mine operations cease in } \\
1969\end{array}$ & \\
\hline \multicolumn{4}{|l|}{ 1968-1969 } \\
\hline 1970 & & $\begin{array}{l}\text { Mining activity resumes at previous } \\
\text { rate due to discovery of new seams; } \\
\text { floatation processing used for enrich- } \\
\text { ment }\end{array}$ & $\begin{array}{l}\text { Second tailings } \\
\text { (upper) basin con- } \\
\text { structed; begins } \\
\text { use }\end{array}$ \\
\hline 1976-1979 & $\begin{array}{l}\text { Montedison transfers mining license to } \\
\text { Fluromine }\end{array}$ & & \\
\hline 1980-1982 & \multirow[t]{3}{*}{$\begin{array}{l}\text { Concession granted to Prealpi } \\
\text { Mineraria in May } 1980\end{array}$} & $\begin{array}{l}\text { Different system used for enriching flu- } \\
\text { orite }\end{array}$ & Basins not used \\
\hline 1982-1985 & & $\begin{array}{l}\text { Mineral floatation processing of fluo- } \\
\text { rite resumes }\end{array}$ & Both basins in use \\
\hline 19 July 1985 & & Tailings Basins fail & \\
\hline
\end{tabular}

cleansing of waste from the new treatment plant. The dam was raised in Pozzole, about $400 \mathrm{~m}$ away from the mineral processing buildings. Rossi (1973) described the site where the basins were built as follows:

"The ground around the clearing was waterlogged: the geotechnical tests revealed that it was not very resistant to the load (as determined by insitu load tests, the breaking stress was $0.2 \mathrm{~kg} \mathrm{~cm}^{-2}$ in some points). For this reason, special care was needed for making the clear water drainage pipeline. The structure was not rigid, but rather composed of a series of monolithic elements, each measuring over $10 \mathrm{~m}$ long and connected by " $G$ ”, joints to allow for distortion resulting from subsidence of the land forming the bottom of the basin. The drainage pipeline ended in a limnological tank to permit monitoring of the physical-chemical and biological conditions of the effluent and their pos- sible correction. These precautions were taken in agreement with the engineers of the Civil Engineering Corps; however, there was concern about clean water being returned to the Stava stream (a tributary of the Avisio River) and rightly so, since it could threaten the aquatic wildlife and damage the power installations of the many sawmills in the valley".

A summary of the geomorphological characteristics of the area selected for construction of the upper basin was obtained by examining geological and topographic maps drawn prior to basin construction and from an interpretative study of aerial photographs taken by the Gruppo Aerofotogrammetrico Italiano in August and October 1954. As shown on the Italian Geological Map (Map No. 22, "Feltre"), nearly the entire area around Pozzole is covered by a layer of moraine from the last glaciations. The average gradient along the axial sector, where the basin was built, is about 


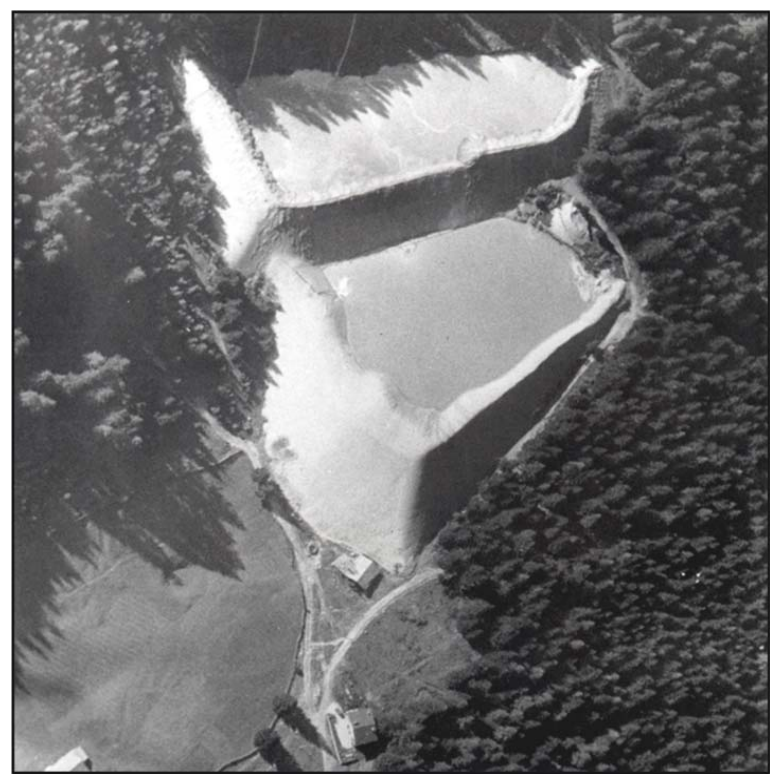

Fig. 5. Aerial view of the basins in October 1973, nearly two years after the construction of upper basin; in this one is in progress the raising of the embankment from the orographic left side (photo Impresa Rossi, Brescia).

$9^{\circ}$. Stereoscopic study of the aerial photographs taken at the time shows an area composed of a broad valley covered with meadows and woodlands, slightly narrower downstream and hollowed out along the central axis. The meadows contain widespread wetlands which appear darker in the photographs due to numerous springs and ponds. Both sides of the valley abutting the dam embankments are composed primarily of colluvial and debris deposits from the slopes of Mount Cucal (layers of sandstone and limestone) and Pala di Santa (rhyolitic volcanics), respectively.

No aerial documentation dating from the 1960s was found, which could allow the progressive development of the basins to be followed. Nonetheless, it was clear from interviews with local residents that the lower impoundment dam was $11 \mathrm{~m}$ high in 1967 and was raised to approximately $23 \mathrm{~m}$ by 1985 . Dam raising for the upper impoundment began in 1970-1971. An aerial photograph taken in October 1973 (Impresa di Rilevamento Aereo Rossi, Brescia) (Fig. 5) shows that the basin had already been in use for at least several years and that the embankment had reached an altitude of $1363 \mathrm{~m}$, approximately $12.2 \mathrm{~m}$ in height over the dam crest of the lower basin $(1350.80 \mathrm{~m})$.

The aerial photograph taken in October 1973 shows that, in the lower basin, water pooled on the surface delimited by the embankment, directly reaching the sandy restraint levee and submerging the previously mentioned "beach" formed by silts to protect the internal facing. A pipeline leading from the upper impoundment and running along the crest of the lower dam (right side), gave rise to a small "delta", emerging from the water and measuring a few square meters in area.

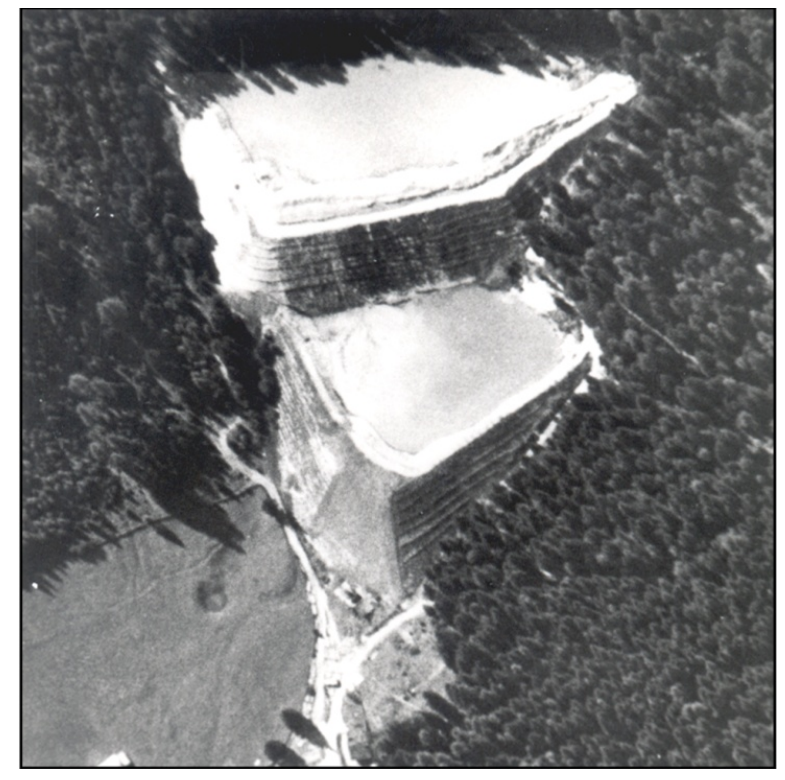

Fig. 6. The decantation basins photographed in September 1978 . The geometry of the upper basin seems altered with respect to the previous photo: works to raise the embankment according to the scheme "upstream" are clearly in progress (photo Impresa Rossi, Brescia).

The entire surface of the sub-rectangular upper impoundment was also covered by water, which appeared very cloudy and was in direct contact with the embankment almost everywhere. Dam raising with the cyclone method was clearly in progress on the left side, starting from the crest of the basin's northern end.

An aerial photograph taken in September 1978 (Fig. 6) shows that while the geometry of the lower basin had remained basically unchanged, that of the upper basin appears planimetrically and altimetrically different from previous photographs. The crest of the embankment was estimated to be at $1373 \mathrm{~m}$ or about $10 \mathrm{~m}$ higher than in 1973. A few meters further down, a berm, built to break the steep gradient of the external face $\left(39^{\circ}\right)$, ran along the entire perimeter of the embankment at an average elevation of $1371 \mathrm{~m}$. Also in this photograph, evidence of dam raising can be clearly observed on the left side, starting from its northern end. The basin appears slightly extended, forming a triangle towards its northern end and reaching further upstream.

As in the lower impoundment, water appeared to be in direct contact with the embankment almost everywhere. An exception was the connection sector with the upper embankment, where there was an exposed deposit large enough to take up the basin's southwestern corner. In this sector, the dam crest was arranged and remodeled. The external face of the lower embankment basin was covered by grass. 


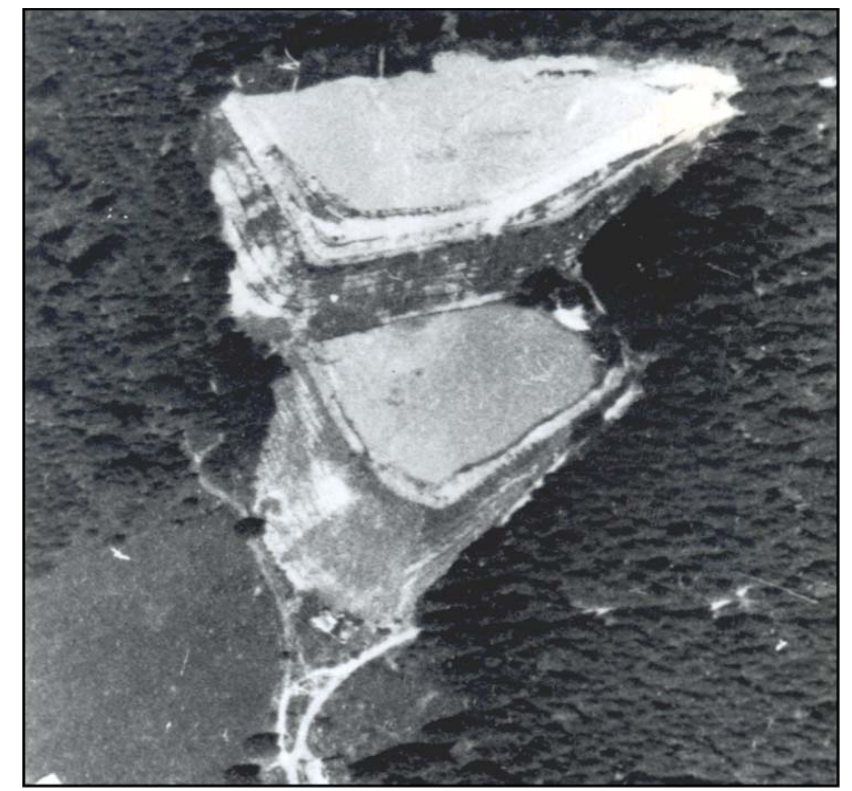

Fig. 7. The Pozzole basins in the summer 1983. The top of the upper embankment appears amply broadened and leveled. Also noticeable is the development of the delta deposit at the left end of the upper basin, next to the place of cyclone operation (photo Impresa Rossi, Brescia).

An aerial photograph taken in 1983 (Fig. 7) reveals the later changes mainly involving the upper impoundment. It demonstrates more or less completed banking of the entire embankment. By this time it had reached an altitude of $1376 \mathrm{~m}$, about $3 \mathrm{~m}$ higher than in 1978 and about $13 \mathrm{~m}$ higher than in 1973. In both basins, the water appears whitish and very murky. The upper impoundment is more significantly enlarged by the deposit at "delta" fed by the cyclone installed at the basin's northern end. Along the south side and frontally, water touches the internal face of the embankment.

The aerial photograph taken in 1983 shows very noticeable lighter, elongated patches on the external face and the right side of both embankments. Almost all the embankment of the upper basin appears raised in comparison with the previous image and the height was realized using the "upstream" construction method.

No photographic documentation was available for the period between autumn 1983 and July 1985. From the land survey carried out on behalf of the Court of Trento on the embankment sectors that remained from the left bank of the upper basin, it appears that the height of the dam crest on the day of the disaster was $1378.83 \mathrm{~m}$. Therefore, it can be reasonably assumed that, at least in part, the dam had been raised by $5.83 \mathrm{~m}$ over the height estimated from the aerophotogrammetric map of 1983. In summary, from 1971 until the collapse of 19 July 1985, the height of the upper impoundment dam was increased by about $28 \mathrm{~m}$.

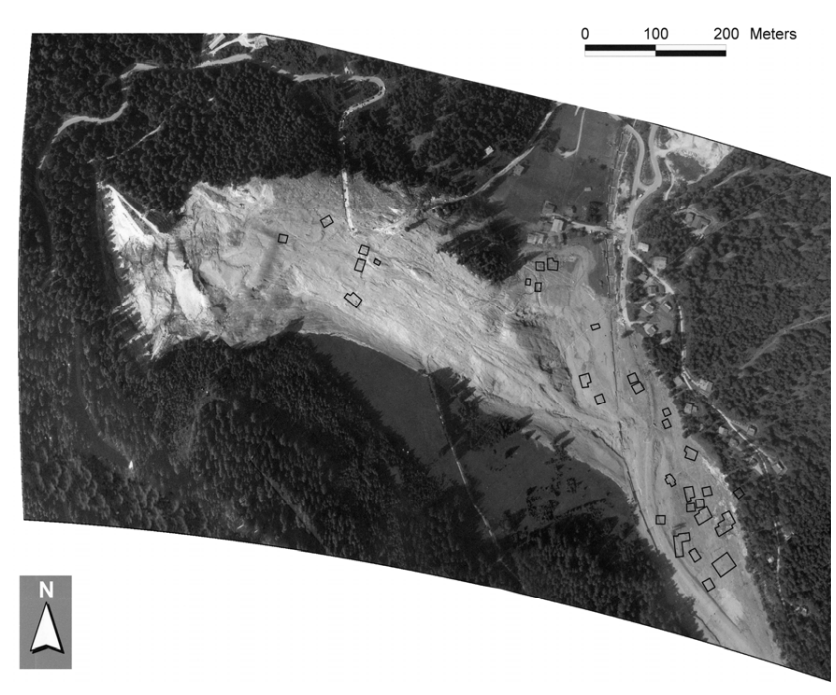

Fig. 8. The Pozzole basins and the upper part of the mudflow a few hours after the disaster. The large displacement of dam material is observable in the frontal sector of the upper embankment and the tracks of the scarps for the detachment and outflow of the materials deposited in the basin. On the left side, the sandy-silty deltaic deposit has remained almost completely in place. The remains of the lower embankment appear slightly in relief under the muddy covering. The photograph, processed using ArcView GIS and thus slightly deformed due to the collimation with the elements of the Regional Technical Map, shows the traces of the external walls of the destroyed buildings (photo Aeron. Mil., conc. S.M.A. no. 623, 19 July 1985).

\section{The mudflow along the Stava valley}

The following is an examination of the dynamics of the Stava valley mudflow reconstructed from surveys conducted starting the day after the disaster, eyewitness accounts, and analysis of the documentation. The Pozzole basin embankments failed at 12:22:55 on 19 July 1985, accompanied by a "hollow rumble" that some eyewitnesses said sounded like a "strong blast of explosives being detonated". A large mass of mud poured from the upper to the lower impoundment and then flowed downslope below (Fig. 8), spreading laterally in a wave at least $250 \mathrm{~m}$ wide upstream from the village of Stava. Hundreds of tall trees (spruce and larch) were literally "cut down" just above the roots (Fig. 9). People living on the slope opposite the Pozzole basin stated that "the trees were swept off the ground" by the shock wave of air pushed forward by the moving mass. Air blasts causing a similar effect proceeded some large, rapidly-moving rock falls (Wieczorek et al., 2000).

After destroying houses on the hillside below the impoundments, the mudflow hit Stava on the valley floor, a village composed of about 20 buildings on the left bank of the stream (Fig. 10). In this area of confluence between the Pozzole basin and the Stava valley, the muddy mass was forced to follow a superelevated path that curved to the right $(650 \mathrm{~m}$ 


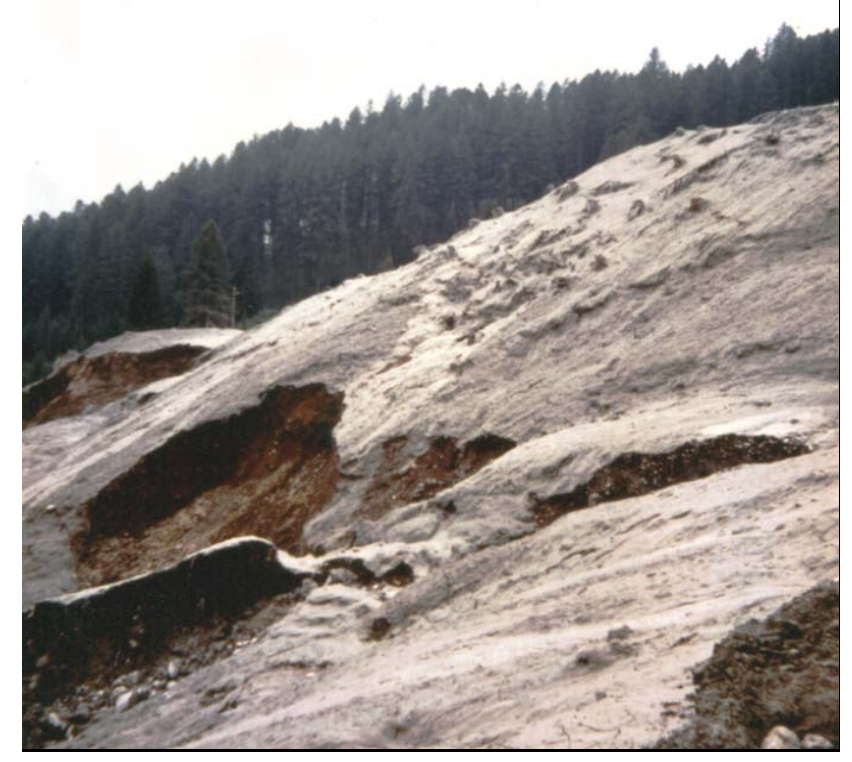

Fig. 9. A slope sector at the foot of the Pozzole basins, just upstream the Stava village. The photograph shows a thin layer of mud left behind as the mudflow moved downstream. The effects on the ground and the destructive effects on forest cover are also visible (photograph CNR-IRPI Torino, 20 July 1985).

in radius), which considerably increased its thickness on the opposite side. Specific trigonometric measurements registered a maximum difference in height of about $19 \mathrm{~m}$ compared to the minimal thickness found on the right side of the valley (Govi and Luino, 2003). Stava, therefore, suffered the most devastating effects; it was completely razed to the ground (Fig. 11, sections 4 and 5 and Fig. 12).

In the plain just downstream from Stava, the translational motion slowed down, which affected its width. This flat sector was the site of mud deposition in significantly greater amounts (thickness $=1-3 \mathrm{~m}$ ) than elsewhere in the valley. There was also abundant ponding of water primarily due to containment by the road embankment of the village. To allow rescue teams access through the fluid mass, the road embankment had to be cut to drain the murky water. The width of the mudflow (in cross section), already reduced near Stava, decreased by nearly half at $850 \mathrm{~m}$ downstream from the village. The width of the mudflow track gradually decreased in area along this segment. A more marked decrease (from $800 \mathrm{~m}^{2}$ to $460 \mathrm{~m}^{2}$ ) began downstream from Maso Sfronzon (Fig. 11, sections 8 and 9). This may have been due to acceleration of the movement and loss of material deposited at a morphological step protruding from the left side, which narrowed the valley.

All along the next segment of more than $1.6 \mathrm{~km}$, up to the first houses in Tesero, the fluid mass moved with relatively greater continuity because of channeling in narrower sec-

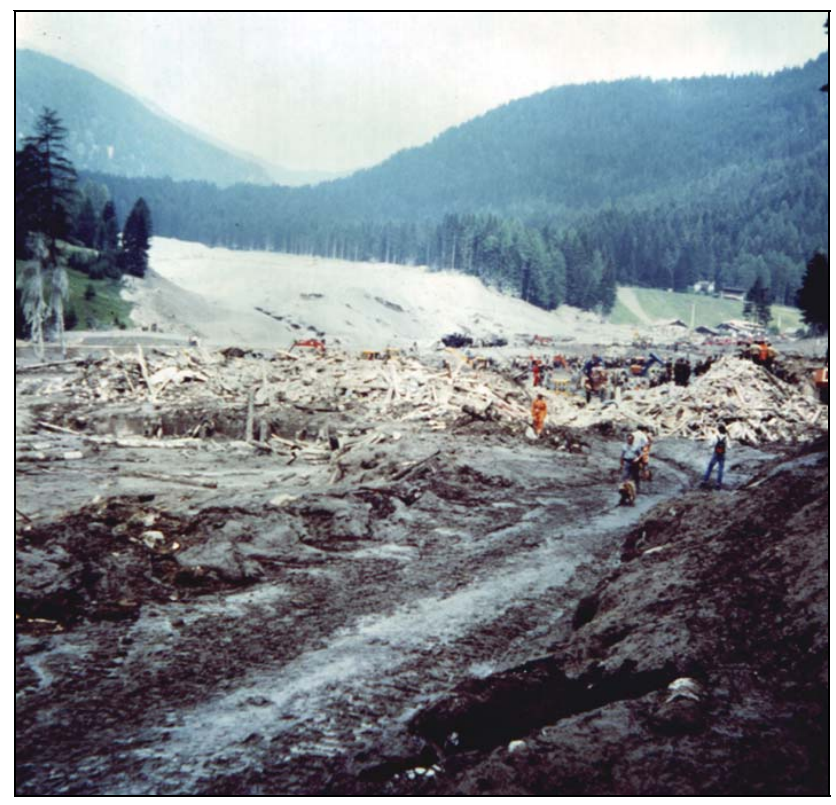

Fig. 10. Area where Stava village once stood. The mudflow in this urbanized sector reached a maximum height of $14 \mathrm{~m}$ in the middle of the valley bottom; all buildings were destroyed at the ground level. The mud-covered Pozzole slope (Fig. 6) is visible in the upper left side of the picture (photograph CNR-IRPI Torino, 20 July 1985).

tions, although with more or less large fluctuations in crosssectional width and height depending on the sectors where the mudflow had to adapt to the narrowing and curvature of the valley axis. The width of the track occupied by the mudflow decreased progressively from $90 \mathrm{~m}$ to $50 \mathrm{~m}$ (minimum value) in the segment immediately downstream from the football field in Tesero (Fig. 11, section 15). In this segment, the size of the moving mass was significantly reduced by deposits left on the right side of the valley and because of the collapse of industrial buildings just upstream from the football field.

With the debris picked up along its path, the mudflow regained some volume and proceeded downstream, with greater pulsated movement of translation. Nearly the entire row of buildings on the right bank of the Stava stream in Tesero was completely destroyed (Fig. 13). Also in this case, an eyewitness on the higher bridge in Tesero a few minutes before 12:30 said he saw some superstructures of the sawmill, about $500 \mathrm{~m}$ upstream, "go flying" a few seconds before the mudflow hit them (Govi and Luino, 2003). Just upstream from Tesero there are two arch bridges. The older bridge was built at the beginning of the 19th century and the other one much more recently. Their respective height is 16 and $19 \mathrm{~m}$ over the valley bottom. The mudflow slowed significantly and swelled in height because of the curvature of the narrow valley and because of the bridge underpasses, especially the narrower span of the older bridge. A portion of 


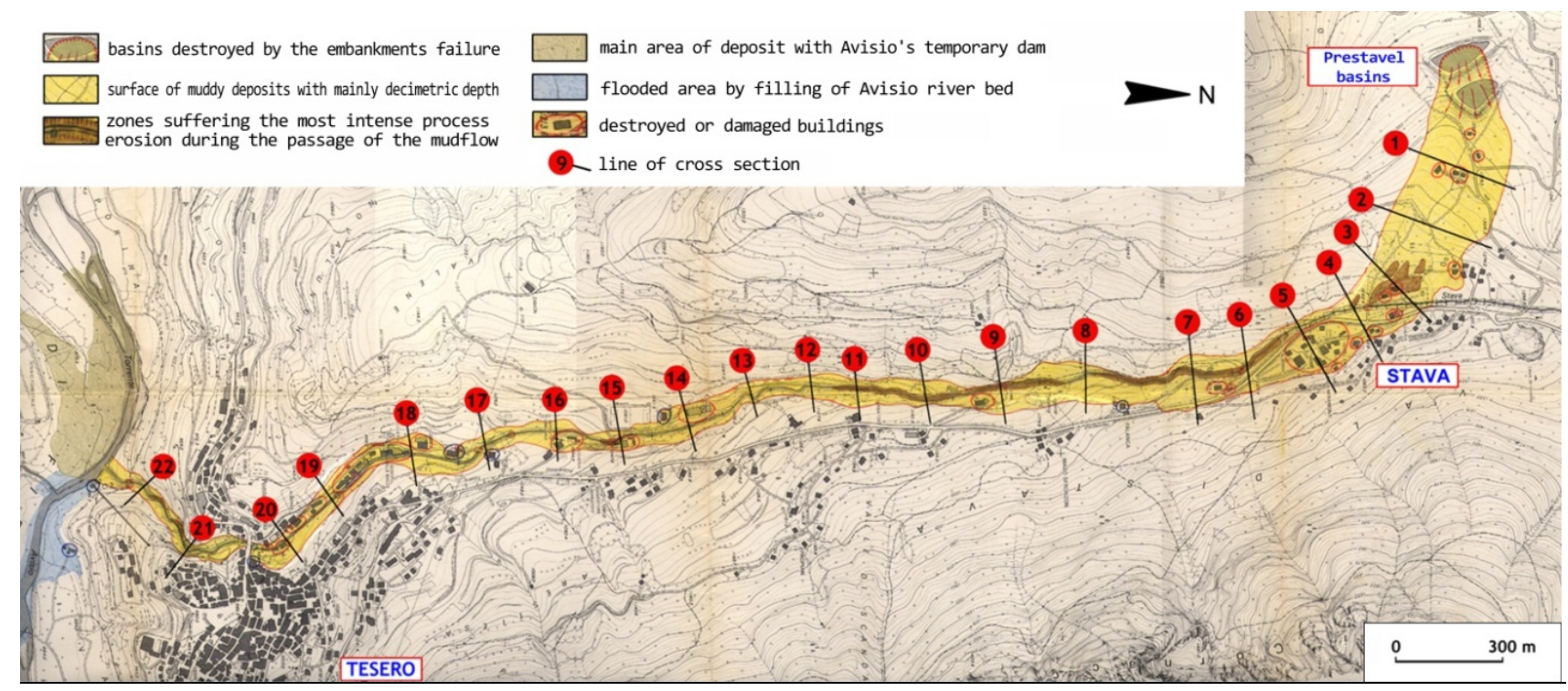

Fig. 11. Mudflow path of 19 July 1985 along the Stave Valley showing different effects observed by the geologists of CNR-IRPI, Torino during the first surveys. The locations of 22 cross-sections measured during the survey are highlighted. The original map base is $1: 5000$ scale (from Govi and Luino, 2003, modified).

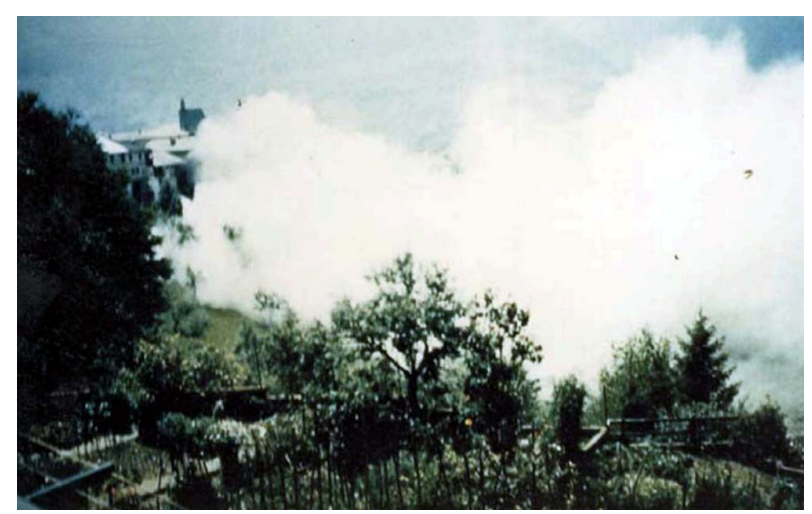

Fig. 12. The shocking moment in which the mudflow, preceded by a white cloud, reached the urbanized areas on the valley bottom of Tesero (courtesy of Fondazione Stava, 1985).

the fluid mass overflowed the older bridge and partially removed the roadway. In this section the mud track on the left side was $10 \mathrm{~m}$ higher than those observed on the right side, with a maximum height on the left of about $18 \mathrm{~m}$ above the valley bottom (Fig. 14).

Channeled into the deep incision downstream from the two bridges, the mass rapidly reached the area of confluence of the Stava and Avisio rivers, where the mudflow gradually came to rest. The wide, fairly flat valley bottom allowed the mud materials to deposit over an area of approximately $100000 \mathrm{~m}^{2}$. The flat, displaced mass that accumulated in the Avisio riverbed formed a dam upstream from the confluence and formed a lake $500 \mathrm{~m}$ long (Fig. 15).

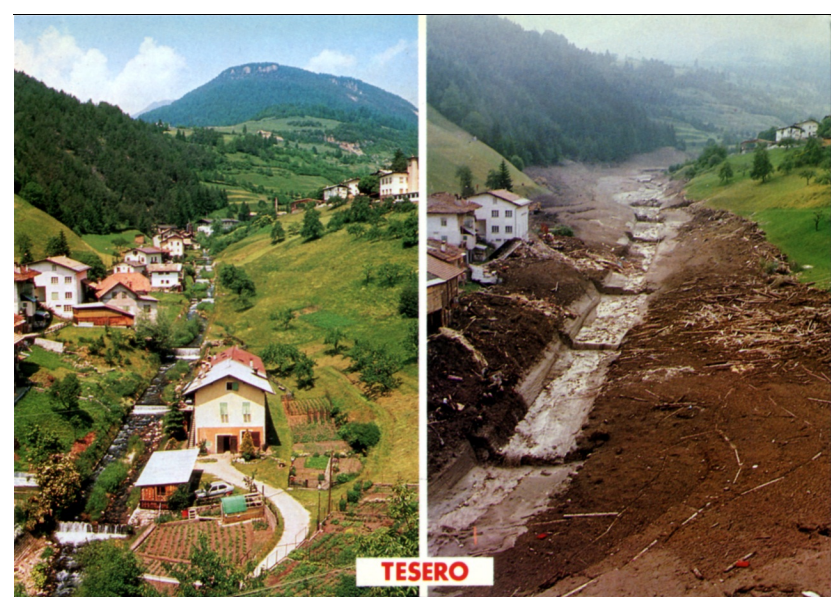

Fig. 13. Before and after the passage of the mudflow in the Tesero village at section 20 in Fig. 8 (postcard - Foto Trettel, P., edited by: Artesan, Tesero).

The loss of lives and property along the entire path of the mudflow from the impoundments to the Avisio River was enormous: 268 people died; 56 houses and 6 industrial buildings destroyed; 8 bridges demolished; and 9 buildings severely damaged. The mudflow left behind a thick layer of mud, between 0.20 and $0.40 \mathrm{~m}$ high in many places, covering an area of about 43.5 ha in planimetric surface and $4.2 \mathrm{~km}$ long. According to the profiles, the total quantity of material from the two impoundments was about $180000 \mathrm{~m}^{3}$. Added to this quantity were $40-50000 \mathrm{~m}^{3}$ resulting from erosion along the valley (extending over a total area of $2.7 \mathrm{ha}$ ), 


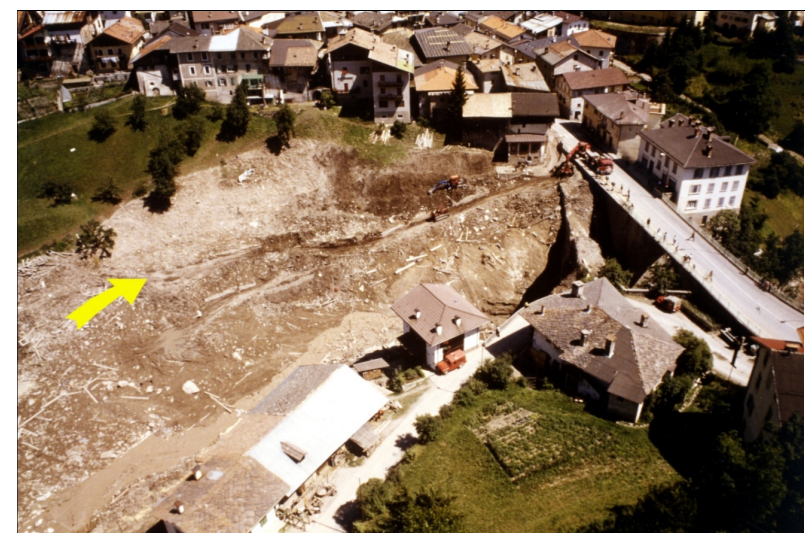

Fig. 14. The effects produced by the mudflow in Tesero, upstream of the two bridges. For the curvature of the axis to the right valley, the mass raised considerably on the left side to $10 \mathrm{~m}$ more than the right bank (photo CNR-IRPI Torino, 20 July 1985).

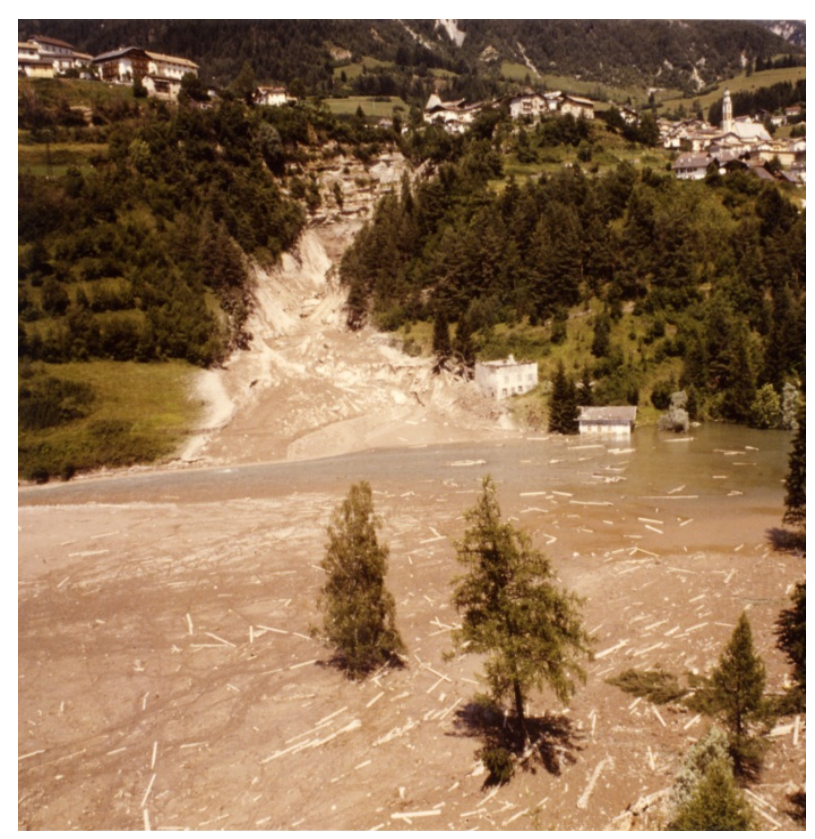

Fig. 15. Stava creek at the confluence with the Avisio River. In its final confined stretch, the mudflow triggered significant erosion of both sides of the valley and the valley bottom. Along the path, all the trees were removed. On the margins, mud marks reached the tops of trees up to $25 \mathrm{~m}$ height above the valley floor. In the river bed of the Avisio River, a basin was created that extended about 10 ha in total (deposit forming the dam plus the lake behind it) (photo CNR-IRPI Torino, 20 July 1985).

including the destruction of buildings and uprooting of hundreds of trees along the mudflow path until reaching the Avisio River. Of note is that numerous tree trunks were deposited in long levees on both sides of the mudflow, together with the coarser and heavier materials the mass movement had picked up and carried with it (Fig. 16).

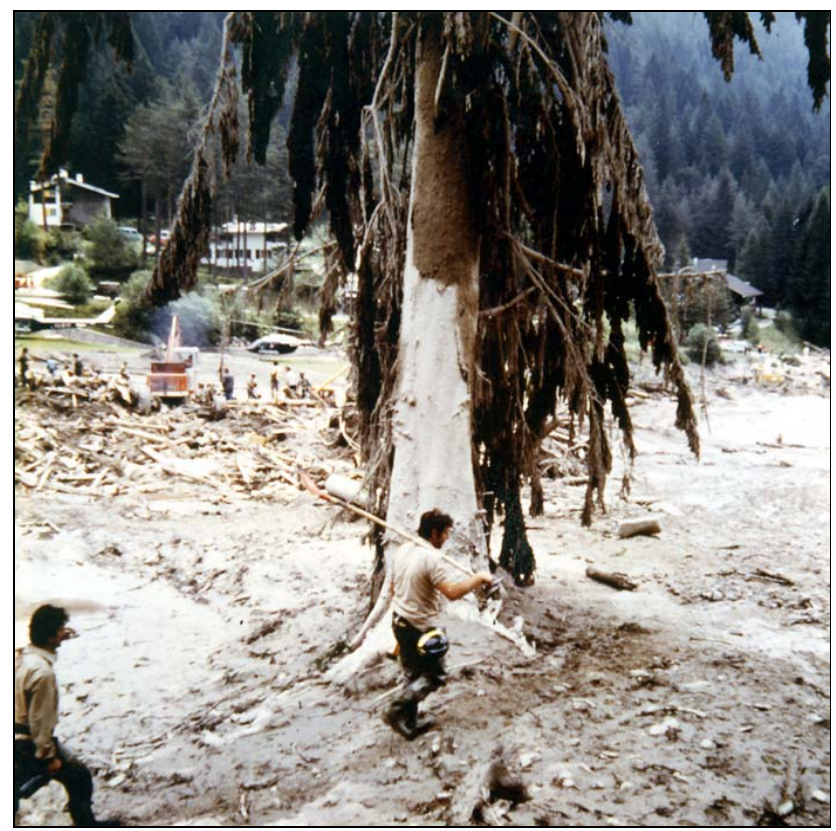

Fig. 16. Just upstream from Stava village, the mudflow had a remarkable height despite its obvious width. This is evident by signs of barking on the tree (by abrasion of the densest part of the mudflow) and by the apparent heaviness of the foliage widely covered by mud (as a result of the higher and smoother of the mudflow). Some of the trees and coarser material deposited as levees along the track are visible in the background (photograph CNR-IRPI Torino, 20 July 1985).

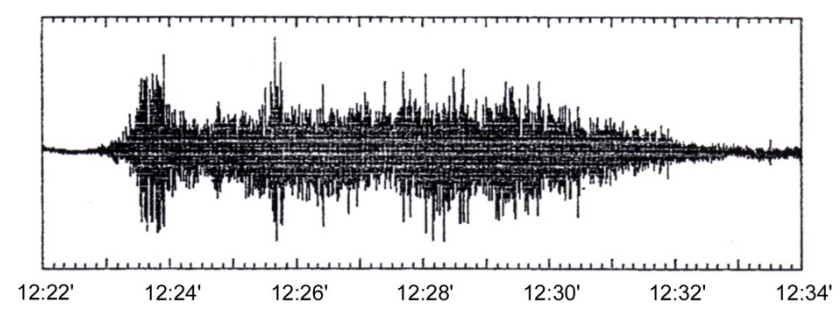

Fig. 17. Seismogram recorded at Cavalese station on 19 July 1985 , from 12:22 to $12: 34$.

While the aftermath of the event provided evidence of how it had taken place and what its impacts were, the rapid course of events could only be roughly estimated from eyewitness accounts and field measurements at selected points. From a seismogram recorded at the nearby Cavalese station (Fig. 17), it was possible to estimate the time intervals during which the tailings basins failed, the mudflow was triggered, and its destructive passage along the Stava valley took place (Table 2). Cavalese station is located only $4.1 \mathrm{~km}$ from the Prestavel basins. Takahashi (1991) used the seismogram to interpret the sequence of events during the disaster and develop estimates of the velocity the mudflow attained at various points along its track. Physical measurements of the 
Table 2. Analysis of the time intervals from the first vibrations to the final deposition of solid-liquid mixture in the Avisio Valley.

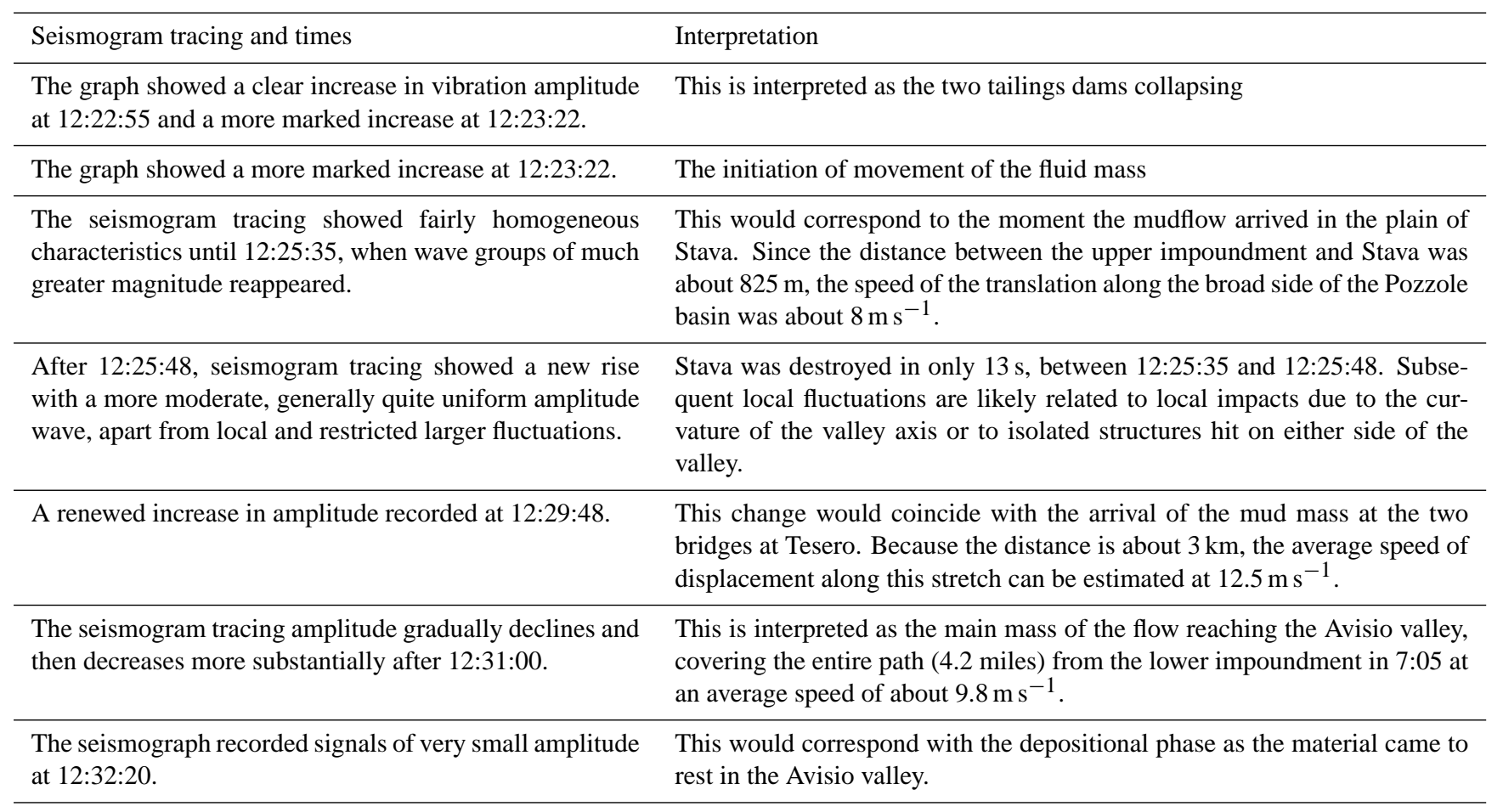

velocity of the mudflow passage were made at selected points along the track. The velocity of the mudflow passage was estimated by measuring the mudflow height on the external bank versus the internal bank at Stava (where the mudflow entered a wide curve). Speeds ranged from $20 \mathrm{~m} \mathrm{~s}^{-1}$ (sections 4 and 6 in Fig. 11) to $27 \mathrm{~m} \mathrm{~s}^{-1}$ (sections 5 in Fig. 11). These results corresponded closely to those calculated by Takahashi (1991).

\section{Critical analysis of the technical literature on mine tailings dams}

Dams have been utilized for water supply and/or flood control purposes for thousands of years. Since the end of the 19th century, dams have been developed for hydroelectric power generation and more recently also for the retention of industrial byproducts, such as mine tailings. Mine tailings dams in many cases exceed the size of conventional water supply, flood control or hydroelectric dams (Davies, 2002). Despite their dimensions, tailings dams have only gained recognition as a serious safety hazard since the late 1960s and early 1970s when tailings dam failures became more frequent than failures of conventional dams (ICOLD, 1995).

Review of the literature highlighted that the problem of mine tailings materials disposal has been tackled only in relatively recent years and that the focus of attention has shifted away from a primarily cost-driven orientation to one driven by an increasing number of accidents due to poor dam stability, often with heavy loss of lives and extensive damage, difficulty in finding suitable sites for storing ever greater volumes of waste material produced by rapid growth in mining activities, and complex technical and economic problems associated with environmental protection, mine reclamation and potential pollution from waste materials.

While the safety records of conventional water-retention dams have improved during the last 40 years, the record for dams impounding mine tailings continues to be associated with a high rate of failure (Davies, 2002). This difference in the safety records for these two types of dams attracted major attention starting in the early 1970s. A series of catastrophic events occurred between 1965 and 1985 (Table 3), which increased tailings dam awareness among the general public and government bodies. Some governments reacted by implementing new legislation and regulations for stricter control and improvement of mine tailings disposal. Technical-scientific reports were presented at national and international meetings and specific studies were published in technical geology and mining engineering journals. Notable among these national and international meetings were Tailing Disposal Today (Tucson, USA), November 1972 and (Denver, USA), October 1978; Mine Drainage Symposium (Denver, USA) May 1979; and First International Mine Water Congress (Budapest, Hungary) April 1982. 
Table 3. Distance traveled and speed of the mudflow that occurred due to the failure of tailings dams in the period 1965-1985.

\begin{tabular}{|c|c|c|c|c|c|}
\hline $\begin{array}{l}\text { Site } \\
\text { Country } \\
\text { Date }\end{array}$ & Ore type & $\begin{array}{l}\text { Tailings released } \\
\left(\text { million } \mathrm{m}^{3}\right)\end{array}$ & $\begin{array}{l}\text { Distance } \\
\text { traveled } \\
(\mathrm{km})\end{array}$ & Speed & $\begin{array}{l}\text { Factors contributing to failure } \\
\text { impacts }\end{array}$ \\
\hline $\begin{array}{l}\text { EL COBRE } \\
\text { (Chile) } \\
28 \text { March } 1965\end{array}$ & Copper & 2.25 (WUP, 2011) & $\begin{array}{l}7.8(\text { WPC }) \\
12 \quad \text { (WUP, } \\
2011)\end{array}$ & $\begin{array}{l}\text { About } 50 \mathrm{~km} \mathrm{~h}^{-1} \\
\text { (WP) }\end{array}$ & $\begin{array}{l}\text { Earthquake-initiated (USGS); lique- } \\
\text { faction; upper parts of recent dam } \\
\text { deposits not yet strengthened (Dobry } \\
\text { and Alvarez, 1967). }\end{array}$ \\
\hline $\begin{array}{l}\text { SGORIGRAD (Bulgaria) } \\
1 \text { May } 1966\end{array}$ & $\begin{array}{l}\text { Lead, zinc, cop- } \\
\text { per, silver }\end{array}$ & 0.45 (WUP, 2011) & $\begin{array}{l}6 \\
2011) \\
8 \\
2011)\end{array}$ (WTI, & $\begin{array}{l}\text { Probably about } \\
30 \mathrm{~km} \mathrm{~h}^{-1} \text { ("Distance } \\
\text { covered within a few } \\
\text { minutes") }\end{array}$ & $\begin{array}{l}\text { Initiated by 3-days of intense rainfall; } \\
\text { location of dam blocked natural val- } \\
\text { ley; stream diversion fails; dam col- } \\
\text { lapse due to seepage (Lucchi, 2009). }\end{array}$ \\
\hline $\begin{array}{l}\text { ABERFAN } \\
\text { (Wales-UK) } \\
21 \text { October } 1966\end{array}$ & Coal & 0.16 (WUP, 2011) & $\begin{array}{l}0.6 \\
2011)\end{array}$ (WUP, & $\begin{array}{l}\text { About } 18 \mathrm{~km} \mathrm{~h}^{-1} \\
\text { (Waltham, 1978) }\end{array}$ & $\begin{array}{l}\text { Triggered by intense rainfall; tailings } \\
\text { placed on steep hillside; hillside lo- } \\
\text { cation hosted numerous springs (Bolt } \\
\text { et al., 1975); underestimated signif- } \\
\text { cance of earlier instability (Mancini, } \\
\text { 1967); rapid movement not antici- } \\
\text { pated (Waltham, 1978). }\end{array}$ \\
\hline
\end{tabular}

\begin{tabular}{llll}
\hline $\begin{array}{l}\text { FORT MEADE } \\
\text { (Florida-USA) }\end{array}$ & Phosphate & 9 (WUP, 2011) & $\begin{array}{l}120 \\
2011)\end{array}$
\end{tabular}$\quad \begin{aligned} & \text { (WUP, } \\
& \begin{array}{l}\text { About 30-36 km h } \\
\text { (Kulesza, 2011) }\end{array}\end{aligned}$

Dam height: $15 \mathrm{~m}$; the cause is unknown, although the dam was observed to have been intact and with no signs of distress $15 \mathrm{~min}$ before the failure occurred (Lucia et al., 1981).

\begin{tabular}{|c|c|c|c|c|c|}
\hline $\begin{array}{l}\text { BUFFALO CREEK } \\
\text { (West Virginia-USA) } \\
26 \text { February } 1972\end{array}$ & Coal & $\begin{array}{l}0.5 \\
(\mathrm{WUP}, 2011)\end{array}$ & $\begin{array}{l}27 \\
2011)\end{array}$ (WUP, & $\begin{array}{l}\text { About } 12 \mathrm{~km} \mathrm{~h}^{-1} \\
\text { (Waltham, 1978) }\end{array}$ & $\begin{array}{l}\text { Tailings used as water impound- } \\
\text { ment dam; impounded water seeped } \\
\text { through tailings; collapse on dam face } \\
\text { permitted overtopping by impounded } \\
\text { water (Waltham, 1978); } 144 \text { casual- } \\
\text { ties (WUP, 2011). }\end{array}$ \\
\hline
\end{tabular}

\begin{tabular}{llll}
\hline $\begin{array}{l}\text { BAFOKENG } \\
\text { (South Africa) }\end{array}$ & Platinum & 3 (WUP, 2011) & $\begin{array}{l}45 \\
2011)\end{array}$
\end{tabular} (WUP, $\begin{aligned} & \text { Less than } 40 \mathrm{~km} \mathrm{~h}^{-1} \\
& \text { (Blight et al., 1981) }\end{aligned}$

Intense rainfall; An embankment failure by concentrated seepage and piping cracks provoked a mudflow of about 3 million of cubic meters: 125 victims (WUP, 2011). Pollution reached the Kwa Leragane River and the Vaalkop reservoir.

\begin{tabular}{lllll}
\hline $\begin{array}{l}\text { MOCHIKOSHI } \\
\text { (JAPAN) }\end{array}$ & No.1 & Gold & 0.08 (WUP, 2011) & $\begin{array}{l}7-8 \\
\text { 2011) }\end{array}$ \\
14 January 1978 & & & &
\end{tabular}

14 January 1978

\begin{tabular}{|c|c|c|c|c|}
\hline $\begin{array}{l}\text { MOCHIKOSHI } \\
\text { (JAPAN) } \\
\text { 14 January } 1978\end{array}$ & Gold & 0.08 (WUP, 2011) & $\begin{array}{l}7-8 \text { (WUP, } \\
2011)\end{array}$ & $\begin{array}{l}\text { Earthquake-initiated (M7.0); lique- } \\
\text { faction; dam height: } 28 \mathrm{~m} \text {; the dam } \\
\text { watchman that witnessed this catas- } \\
\text { trophic event said "within about } 10 \mathrm{~s} \\
\text { of the shaking, the frontal wall of the } \\
\text { dam swelled causing excessive verti- } \\
\text { cal movements at the crest" (Ishihara, } \\
\text { 1984). }\end{array}$ \\
\hline $\begin{array}{l}\text { CHURCH ROCK } \\
\text { (New Mexico-USA) } \\
16 \text { July } 1979\end{array}$ & Uranium & 0.37 (WUP, 2011) & 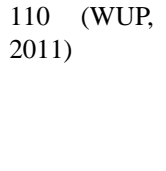 & $\begin{array}{l}\text { The largest radioactive accident in } \\
\text { US history. Dam wall breach due } \\
\text { to differential foundation settlements; } \\
\text { contamination of Rio Puerco (WUP, } \\
\text { 2011). }\end{array}$ \\
\hline $\begin{array}{l}\text { TYRONE } \\
\text { (New Mexico-USA) } \\
13 \text { October } 1980\end{array}$ & Copper & 2 (WUP, 2011) & $\begin{array}{l}8 \text { (WUP, } \\
2011)\end{array}$ & $\begin{array}{l}\text { Dam wall breach due to fast increase } \\
\text { in dam wall height ( } 66 \mathrm{~m} \text { ), provok- } \\
\text { ing high internal pore pressure (WUP, } \\
2011) ; 300 \text { acres inundated; the force } \\
\text { of the flood downed power lines and } \\
\text { broke water mains (Huggard, 1994). }\end{array}$ \\
\hline $\begin{array}{l}\text { VETA DE AGUA No } 1 \\
\text { (Chile) } \\
3 \text { March } 1985\end{array}$ & Copper & 0.28 (WUP, 2011) & $\begin{array}{l}5 \\
2011)\end{array}$ & $\begin{array}{l}\text { Dam height: } 24 \mathrm{~m} \text {; Earthquake- } \\
\text { initiated (M7.8); liquefaction (Castro } \\
\text { and Troncoso, 1989). }\end{array}$ \\
\hline
\end{tabular}


From an analysis of this extensive literature, the following points can be made with reference to basin construction and management and safety conditions of containment plants. Among the various construction methods usually adopted for earth dam raisings (downstream method, central axis method, upstream method), the last is recognized as the least suitable in terms of dam stability, because stability characteristics gradually worsen with increasing dam height (Brawner and Campbell, 1973; Rossi, 1973; Bauer, 1978; Klohn, 1979; Robinson, 1979; Watermayer and Williamson, 1979; Highter and Tobin, 1980; Lebegue, 1985; Cedergren, 1998; Salgueiro et al., 2008). According to some authors, this is mainly due to the construction method, which involves dam raising on silts, which in large part are not yet consolidated. Highter and Tobin (1980) summarized the resulting factors influencing future instability arising from this method as: (a) increased pore pressure in the underlying fine material; (b) differential settlement in the body of the embankment with the potential development of longitudinal cracks; (c) establishment of suspended groundwater with roughly horizontal filtration towards the external face of the dam, facilitated by an alternation of silty and sandy materials; (d) high susceptibility of unconsolidated materials to disaggregate not only because of the application of cyclical strains, but also because of the impulsive action of overloads or the effect of a rapid collapse (see also Nyren et al., 1979).

Several authors underlined the fundamental requirement of preventing any direct contact between the decantation water and the embankment. This can be achieved by creating a strip of fine sand and silt (beach formed by a series of delta welded together) near the dam, but peripheral to the area of invasion, with the aim of extending and lowering the groundwater path to prevent direct filtration through the embankment body and seepage into its external face. This implies the need for continuous monitoring systems to control the water height in the basin and assess drainage efficiency (Swaisgood and Toland, 1973; Klohn, 1979; Robinson, 1979; Watermayer and Williamson, 1979; Isaacs and Hunt, 1981; Lebegue, 1985, László, 2006).

The most common root causes of many accidents (largely unreported because their consequences were not serious) result from the effects of liquefaction and filtration processes, with removal of fine materials in the body of the embankment along "pipes and siphons" (Swaisgood and Toland, 1973; Brawner and Campbell, 1973; Klohn, 1979; Robinson, 1979; Novak et al., 2006; Tosatti, 2007; Braja, 2010).

Tailings basin stability can be affected by all sorts of factors that concur in various ways. One factor mentioned in studies is the original basin dam design and whether, starting from its initial construction stage, it can take into account eventual changes in relation to the production of materials from mining operations. Mittal and Morgenstern (1975) point out that the monitoring of placed materials and pore pressures within the developing structure are critical in ensuring a stable design. Unlike a retaining dam that goes into operation only after its construction has been completed, a tailings waste materials basin is already in operation while still under construction; dam raising progresses in successive stages, often requiring adjustments to make it suitable for the containment of materials with composition and grainsize distribution different from those contemplated in the initial project (Guerra, 1979). These overlooked technical factors are now widely recognized within the mining and engineering community (Mancini, 1976; Williams, 1979; ASCE, 1980; Okusa and Anma, 1980).

In conclusion, a critical point to highlight is that, at least since 1967, (Dobry and Alvarez) and also later (Smith, 1973; Rossi, 1973; McKee et al., 1979; Watermeyer and Williamson, 1979; Lebegue, 1985; Bussière, 2007; Rico et al., 2008) tailings will tend to maintain, even for several years, a state of widespread saturation, giving rise to a noticeably very fluid mass of high-potential instability. Owing to their particular characteristics, these materials are highly mobile. As they spill out of the basin, they cause the dam to collapse and spill downstream, generating a mudflow that rapidly covers distances from a few to many kilometers, sometimes with considerable velocity that does not allow the population to be alerted (see Table 3). Not only is this scenario consistent with the mudflow in the Stava Valley (Chandler and Tosatti, 1995), it is also evident in the earlier disasters.

\section{$7 \quad$ Discussion and conclusions}

When the Prestavel mine tailings disposal facility was constructed, and especially during its later stages, the results of studies following tailings dam disasters in other countries were published in international literature. The reports highlighted the main reasons for failures and suggested modalities and procedures for the design, construction and monitoring of tailings impoundments used by mines. Considering the events involving the facility upstream from Stava and the evidence from the history of the basins, it becomes evident that there were several predisposing factors that caused structural instability.

According to statements by the design engineer and company hands that worked on the construction of the upper basin, the surrounding area was known to be swampy due to numerous springs. Similar site hydrology conditions were found at the base of the lower basin and around the foundation of the upper dam and on the slope immediately upstream from the latter.

From interviews with Prestavel mine employees, a fundamental error common to other similar sites, as cited in the literature, was the belief that the silts deposited in the basins would consolidate fairly rapidly after deposition. This optimistic evaluation very probably influenced the dam construction methods and the location of the impoundments in an area just upstream from Stava. Studies on the impounded 
materials showed that the deposits released water much more slowly than assumed; hence, at the time of the disaster, water had already infiltrated the dams and adjacent sediments to such an extent that they would rapidly liquefy.

The assumed, but never demonstrated, notion that the silts impounded in the basins would consolidate quickly served to support the operational increase in the height of the dams. The entire upper basin dam was constructed using the upstream method, which, among alternatives (central axis method or downstream method), implied conditions of potentially greater instability since it required that part of the upper basin dam would inevitably rest on the silts deposited in the lower basin.

On the basis of the data collected on the geometric characteristics of the upper impoundment dam before its collapse, the slope of vast areas of the external wall was 38$39^{\circ}$. From observation of the two remnants of the basin side walls, the structures were found to be composed of fine prevalently same-size sands coming from mill-crushing and grinding, with interlayers of silts and sandy-gravely material borrowed from the slope. The composition of the dam was therefore not homogeneous, as evinced by shear strength tests and horizontal and vertical permeability measurements (ISMES, 1986).

Extensive portions of the drainage system for the discharge of cyclone overflow were submerged in the silts. The tailings materials flowed through two separate pipelines, running from the upper basin and beneath the dam into the lower basin. During the final years of operation, the upper basin was used for depositing water and sediment, whereas only the lower basin was used for decantation. Very probably, where they were submerged in the saturated silts, the drainage pipes failed at least twice during 1985 . These events should have been seen as signaling increasing conditions of system instability.

In late January, about six months before the disaster, local owners of land at the foot of the lower basin reported observing leakage of water and sand from the base of the upper basin just upstream from the point where, following the collapse, the dam wall had broken. The January event was a dense debris flow that extended nearly $200 \mathrm{~m}$ and was attributed to ice in and around the decant pipe. The sudden water burst at the foot of the dam triggered a local slide over one meter deep and several meters wide on the external wall.

Another episode connected with the rupture of a drainage pipe occurred in the lower basin in June 1985, one month before the disaster. The water pool disappeared and at the site of the underground failure, there was a funnel-shaped cavity several meters wide and about $3 \mathrm{~m}$ deep in the sediment. According to local eyewitness accounts, repair works with the installation of bypass pipes were completed only 5-6 days before the dam failure.

A further consideration is the poor safety monitoring by the Prestavel mine management on the widening and raising operations by the subcontractors. Besides raising the height of the upper basin dam crest, the works included the felling of trees on the slope immediately upstream from the basin. This was authorized and carried out in June 1985, with half of the nearly $300 \mathrm{~m}^{3}$ of cut wood hauled by trucks traveling back and forth over the road along the crest of the upper basin dam and carrying loads of up to 80-100 quintals.

In summary, although no single triggering cause can be identified, several factors were seen to emerge, closely linked and consistent with the preparatory events that led to the dam rupture. From the documentation it is clear that there was no permanent installation of instruments for the continuous monitoring of the state of the materials deposited in the two basins or the stability conditions of the dams.

Finally, attention needs to be called to the then piecemeal legislation regulating technical norms for structures pertaining to mines, i.e. works that cannot be exactly defined as dams as they are not designed for water, but rather for the purposes of progressive impoundment concurrent with the construction of an artificial basin. Nevertheless, this partial lack of a mandate for their control does not limit the responsibility that public technical offices can exercise. At that time there was, in fact, much literature on rules to be followed for the proper growth and maintenance of the reservoirs of mine tailings. Perhaps equally important, the legal framework does not exist for local planning authorities to address this risk to their communities. For example, the identified need to monitor conditions in an operational tailings basin, and if required by regulation, could provide local planning bodies with information useful in assessing the level of risk posed to their community. Comprehensive rather than piecemeal legislation would ensure that all interests potentially affected by the presence of these facilities can be addressed. The legitimate concerns for environmental impacts on wildlife or water quality would be balanced and harmonized with those of public safety. Comprehensive regulation would also benefit the companies involved in activities requiring tailings basins by eliminating conflicting standards and providing consistency useful in economic planning.

Acknowledgements. This paper is dedicated to the memory of Mario Govi (1927-2009), first director of CNR-IRPI Torino, a person of remarkable scientific stature and unsurpassed human qualities. His studies and teachings have been very important for all researchers who are working now in the field of natural instability processes.

Edited by: D. Castaldini

Reviewed by: D. Alexander and G. Tosatti

\section{References}

ASCE - National Conference on Environmental Engineering: Proceedings of the ASCE Environmental Engineering Division, Specialty Conference, Roosevelt Hotel, New York, 8-10 July 1980.

Bauer, G. E.: The control and drainage of water in mine tailing dams, in: Symp. SIAMOS, Granada, pp. 1125-1137, 1978. 
Blight, G. E., Robinson, M. J., and Diering, J. A. C.: The flow of slurry from a breached tailings dam, Journal of the South African Institute of Mining and Metallurgy, 1-8, 1981.

Bolt, B. A., Horn, W. L., MacDonald, G. A., and Scott, R. F.: Aberfan, Wales, October 1966, in Geological Hazards, pp. 183-185, 1975.

Braja, Das M.: Principles of Geotechnical Engineering, edited by: Thomson-Engineering, ISBN-13/EAN: 9780534387426, 608 pp., 2010.

Brawner, C. O. and Campbell, D. B.: The tailing structure and its characteristics. A soil engineer's viewpoint, in: 1st Int. Symp. Tailing Disposal Today, Denver, pp. 59-101, 1973.

Bussière, B.: Hydrogeotechnical properties of hard rock tailings from metal mines and emerging geoenvironmental disposal approaches, Canadian Geotechnical Journal, 449, 1019-1052, doi:10.1139/T07-040, 2007.

Castro, G. and Troncoso, J.: Effects of 1985 Chilean Earthquake on Three Tailings Dams. 5a Jornada Chilena de Sismología e Ingeniería Sísmica, Chile, 1989.

Cedergren, H. R.: Seepage, Drainage, and Flow Nets, 467 pp., John Wiley \& Sons, ISBN 0-471-18053-X90000, 1998.

Chandler, R. J. and Tosatti, G.: The Stava tailings dam failure, Italy, July 1985, Geotechnical Engineering, 113, 67-79, 1995.

C.T.A.: Presidenza del Consiglio dei Ministri. Commissione Tecnico-Amministrativa di inchiesta sul disastro verificatosi nel comune di Tesero, località Stava, Relazione, Roma, April 1986 (in Italian).

Davies, M. P.: Tailings Impoundment Failures: Are Geotechnical Engineers Listening? (2000), in: Geotechnical News, pp. 31-36, September 2002.

Dobry, R. and Alvarez, L.: Seismic failures of Chilean tailings dams, Soil Mech. Found. Div., ASCE, 93, 237-260, 1967.

Fondazione Stava: available at: http://www.stava1985.it, 1985.

Govi, M. and Luino, F.: La colata di fango di Stava (Trentino) del 19 luglio 1985, in: A review of scientific contributions on the Stava Valley disaster (Eastern Italian Alps), 19 July 1985, edited by: Tosatti, G., Pitagora Editrice Bologna, ISBN 88-371-1405-2, pp. 359-397, 2003 (in Italian).

Guerra, F.: Controlling the phreatic surface, in: 2nd Int. Symp. Tailing Disposal Today, Denver, pp. 292-326, 1979.

Highter, W. H. and Tobin, R. F.: Flow slides and the undrained brittleness index of some mine tailings, Engineering Geology, 16, 71-82, 1980.

Huggard, C.: Environmental and Economic Change in the Twentieth-Century West: The History of the Copper Industry in New Mexico, PhD diss., University of New Mexico, 1994.

ICOLD: Dam Failures-Statistical Analysis. Bulletin 99, International Commission on Large Dams (ICOLD), Paris, 1995.

Isaacs, L. T. and Hunt, B.: Seepage from free water above impermeable tailings, Journal Geotech. Engin. Div. ASCE, 107, 15631577, 1981.

Ishihara, K.: Post-earthquake failure of a tailings dam due to liquefaction of the pond deposit, in: Proc., Inter. Conf. on Case Histories in Geotechnical Engineering, Rolla, Missouri, vol. 3, pp. 1129-1143, 6-11 May 1984.

ISMES: Indagini geotecniche di laboratorio su materiali provenienti dai bacini Prestavel in località Stava-Tesero, Technical Report for the Team of Experts of the Trento Court, 5 Vols., Bergamo, 1986 (in Italian).
Klohn, E. J.: Seepage control for tailings dams. Symp. Mine Drainage, Proc. of the 1st Int. Mine Drainage Symp, Denver, pp. 671-725, 1979.

Kulesza, R.: Review of Technical Literature on Tailings Dam Failures involving Flow of Tailings, USSD Workshop on Dam Break Analysis Applied to Tailings Dams Denver, 24-26 August 2011.

László, F.: Lessons learned from the cyanide and heavy metal accidental water pollution in the Tisa river basin in the year 2000, NATO Security through Science Series, Management of Intentional and Accidental Water Pollution, pp. 43-50, 2006.

Lebegue, Y.: Exemples de bassins de décantation construits avec la fraction sableuse des rejets, Revue de l'Industrie Minérale, 2, 129-136, 1985.

Lucchi, G. (Ed.): Stava perché, 2nd Edition, edited by: Curcu \& Genovese, Trento, 254 pp., ISBN 88-87534-37-3, 2002 (in Italian).

Lucchi, G.: Sgorigrad - Stava. Identical Disasters, edited by: Arca, Lavis (Italy), 64, ISBN 978-88-88203-52-2, 2009.

Lucchi, G.: L'attività mineraria in Val di Stava, in: Stava-Tesero la ricostruzione e la memoria, 1985-2010, Litotipografia Alcione, pp. 23-50, 2011 (in Italian).

Lucia, P., Duncan, J., and Seed, H. B.: Summary of Research on Case Histories of Flow Failures of Mine Tailings Impoundment, Mine Waste Disposal Technology Proceedings Bureau of Mine Technology Transfer Workshop, Denver, 16 July 1981.

Mancini, R.: Alcune riflessioni sul disastro di Aberfan, Bollettino Associazione Mineraria Subalpina, IV, 3, 315-321, 1967 (in Italian).

Mancini, R.: Il problema delle discariche minerarie: uno sguardo alla recente letteratura tecnica (in Italian), Bollettino Associazione Mineraria Subalpina, 13, 288-314, 1976.

McKee, B. E., Robinson, K. E., and Urlich, C. M.: Upstream design for extension of an abandoned tailings pond, in: 2nd Int. Symp. Tailing Disposal Today, Denver, pp. 210-233, 1979.

Ministero dell'Industria Commercio Artigianato: Relazioni annuali del Servizio Minerario e Statistica delle Industrie Estrattive in Italia, Corpo delle Miniere. Roma, 1935-1980 (in Italian).

Mittal, H. K. and Morgenstern, N. R.: Parameters for the design of tailings dams, Canadian Geotechnical Journal, 12, 235-261, 1975.

Morra, A. and Vighi, L.: Miniera di Prestavel, L'Industria Mineraria nel Trentino-Alto Adige, Economia Trentina, 1-2, 331-345, 1964 (in Italian).

Novak, P., Moffat, A. I. B., Nalluri, C., and Narayanan, R.: Hydraulic Structures, edited by: Taylor \& Francis Ltd. London, 736 pp., 2006.

Nyren, R. H., Haakonson, K. A., and Mittal, H. K.: Disposal of tar sand tailings at Syncrude Canada Ltd, in: 2nd Int. Symp. Tailing Disposal Today, Denver, pp. 56-74, 1979.

Okusa, S. and Anma, S.: Slope failures and tailings dam damage in the 1978 Izu-Ohshima-Kinkai earthquake, Engineering Geology, 16, 195-224, 1980.

Perna, G.: Fluorite. L'Industria Mineraria nel Trentino-Alto Adige, Economia Trentina, XIII, 66-68, 1964 (in Italian).

Rico, M., Benito, G., Salgueiro, A. R., Díez-Herrero, A., and Pereira, H. G.: Reported tailings dam failures: a review of the European incidents in the worldwide context, Journal of Hazardous Materials, 152, 846-852, 2008.

Robinson, K. E.: Case histories of different seepage problems for 
nine tailing dams, Symp. Mine Drainage, Proc. of the 1st Int. Mine Drainage Symp, Denver, 781-800, 1979.

Rossi, G.: I bacini di decantazione dei rifiuti degli impianti di trattamento dei minerali, L'Industria Mineraria, XXIV, 10, 465-480, 11, 525-544, 1973 (in Italian).

Salgueiro, A., Garcia Pereira, H., Rico, M., Benito, G., and DíezHerrero, A.: Application of Correspondence Analysis in the Assessment of Mine Tailings Dam Breakage Risk in the Mediterranean Region, Risk Analysis, 28, 13-23, 2008.

Smith, E. S.: Tailings disposal. Failures and lessons, in: 1st Int. Symp. Tailing Disposal Today, Tucson, pp. 356-375, 1973.

Swaisgood, J. R. and Toland, G. C.: The control of water in tailings structures, in: 1st Int. Symp. Tailing Disposal Today, Tucson, pp. 138-163, 1973.

Takahashi, T.: Debris flows, IAHR Monograph, Balkema, Rotterdam, pp. 92-99, 1991.

Tosatti, G.: La catastrofe della Val di Stava: cause e responsabilità, Geoitalia, 20, 1-5, 2007. (in Italian).

USEPA: Design and Evaluation of Tailings Dams. Technical Report EPA 530-R-94-038, US Environmental Protection Agency, Washington, available at: http://www.epa.gov/osw/ nonhaz/industrial/special/mining/techdocs/tailings.pdf; last accessed February 2012, 1994.
USGS: available at: http://earthquake.usgs.gov/earthquakes/world/ events/1965_03_28.php; last access November 2011.

Waltham, T.: Catastrophe: the violent earth, Macmillan Press, London, pp. 70-79, 1978.

Watermeyer, P. and Williamson, R.: Ergo tailing dam - Cyclone separation applied to a fine grind product, in: 2nd Int. Symp. Tailings Disposal Today, Denver, pp. 369-396, 1979.

Wieczorek, G. G., Snyder, J. B., Waitt, R. B., Morrissey, M. M., Uhrhammer, R. A., Harp, E. L., Norris, R. D., Bursik, M. I., and Finewood, L. G.: Unusual July 10, 1996, rock fall at Happy Isles, Yosemite National Park, California, Geological Society of America Bulletin, 112, 75-85, 2000.

Williams, M. P. A.: Tailings dam failure case history, in: 2nd Int. Symp. Tailing Disposal Today, Denver, pp. 428-433, 1979.

WP: available at: http://www.portalchoapa.cl/detalle.php?seccion= medioambiente\&id=28, last access November 2011 .

WTI: available at: www.tailings.info/index.htm, last access November 2011.

WUP: Wise Uranium Project - Chronology of major tailings dam failures (from 1960), available at: www.wiseuranium.org/, last access November 2011. 